5. Тетеря І. Право довірчої власності. Які наслідки для громадян та бізнесу. Бізнес Цензор: веб-сайт. URL:https://biz.censor.net/columns/ 3156278/pravo_dovrcho_vlasnost_yak_nasldki_dlya_gromadyan_ta_bznesu (дата звернення: 15.10.2020).

DOI https://doi.org/10.30525/978-9934-588-92-1-34

\title{
THE PHENOMENON OF RESTORATION OF THE LIMITATION PERIOD. GROUNDS AND CONSEQUENCES
}

\author{
Guyvan P. D. \\ Candidate of Juridical Sciences, Honored Lawyer of Ukraine, \\ Professor \\ Poltava Business Institute \\ Poltava, Ukraine
}

Judicial protection of the violated subjective right of a person may take place if he / she has filed a claim with the court within the statutory limitation period. In case of omission of the specified term the judicial protective property of the substantive law is repaid. At the same time, the law contains certain guarantees for subjects who missed the time of filing a claim for a good reason: if this fact is established in the process, the violated right is subject to protection. Modern law, based on the civil law principle of guaranteeing the implementation of subjective law [1, p. 105], provides for the possibility of its protection and after the coincidence of the period established for the claim. Part 5 of Article 267 of the Civil Code of Ukraine states that if the court finds valid the reasons for the omission of the statute of limitations, the violated right is subject to protection. It should be noted that the definition of «restoration of the statute of limitations» widely used in law and civilization does not quite accurately reflect the essence of this phenomenon. To be punctual, it is necessary to refer to the literal text of the relevant provision of the Central Committee of Ukraine, which deals with the exercise of the right to judicial protection outside the existence of such a right to protection. Thus, it is a question of restoration of compulsory ability of the protective substantive right, instead of the course of term. Thus such protection will take place already after the termination of existence of the substantive right to the claim owing to one-time renewal of protective legal capacity of the right [2, p. 398]. 
In fact, there is no disagreement in the civilist literature that the term «restoration of the statute of limitations» is conditional, and it is in this guise that it should be used in law enforcement. Indeed, it does not contain the content that concerns the change in the order of calculation of the term. The effectiveness of this mechanism is to give the right holder the opportunity to state protection of his right, when his claim is filed after the deadline, but such omission occurred in good circumstances. It is not a question of restoring the missed deadline, but of restoring the mechanism of judicial protection, which should be applied in a timely appeal to the court. Therefore, the commented terminology is used rather for the convenience of practical application of a certain legal mechanism, the essence of which is set out in Chapter 19 of the CCU. Therefore, in order not to make a methodological error, it is inadmissible to talk about extending the statute of limitations or setting a new deadline.

At the same time, in practice subjective interpretations of the validity of the reasons for the omission of the statute of limitations are not excluded and even the fact of such omission does not seem certain, as a result the law enforcement body unreasonably ignores unjustified omissions, and on the other hand may be dissatisfied on the restoration of the statute of limitations, declared on really valid grounds, but those that go beyond the regulated. The statute of limitations for judicial protection of violated civil law has a moment of beginning and a moment of end. It is during this period that the creditor's appeal to the court may ensure the possibility of enforcement measures of a coercive nature. The civil legislation of Ukraine establishes certain lists of circumstances as a result of which there is a change in the procedure for calculating the statute of limitations (suspension, interruption). In such cases, the length of the period from the initial to the end of this period may increase. But in any case, as a general rule, outside the statute of limitations, subjective substantive law is not secured by legal capacity.

In jurisprudence there is no unanimity about the meaning of the legislator in the concept of restoring the missed statute of limitations. According to some scholars, with the restoration of the statute of limitations, the opportunity to initiate and implement certain procedural measures to protect the violated right is renewed [3, p. 97]. This possibility was lost after the expiration of the statute of limitations, which prevented the beginning of the necessary procedural actions. But after the court resumes the statute of limitations, it reappears and manifests itself in the fact that the relevant process begins. According to the authors of this concept, the restoration of the statute of limitations in good circumstances is the primary phenomenon that precedes the further consideration of the case on the merits. Only after the restoration of the statute of limitations is it possible and expedient to consider the case on the dispute between the parties. And only during this further consideration of the dispute 
can the judicial body establish whether the creditor has a civil right, whether it has been violated by the debtor and, finally, whether it is subject to protection. If the statute of limitations is not restored due to the disrespect of the reasons for its omission, there is no need to analyze the circumstances of the case on the merits, because even in the presence of a clear violation of substantive law, it still can not be protected. Instead, when the court, after the resumption of the missed statute of limitations, concludes that there are no legal grounds to satisfy the claim, it must justify the rejection of the claim by the relevant substantive or procedural law, and not by omitting the statute of limitations, as the issue of protection is already considered. This thesis deserves a critical assessment, because it is an obvious substitution of material categories for procedural ones.

From the point of view of other researchers, the protection of the violated substantive right after the expiration of the statute of limitations can not be considered as the resumption of the process to protect the violated right. Litigation is one of the forms of protection of rights. Protection, according to scientists who advocate such a position, is not a process, but a concrete result - satisfaction of the creditor's claims [4, p. 10]. Article 16 of the Civil Code of Ukraine provides that the ways to protect civil rights and interests are the recognition of the right; invalidation of the transaction; termination of an action that violates the right; restoration of the situation that existed before the violation; enforcement in kind; change of legal relationship; compensation for damages and property damage; compensation for nonpecuniary (moral) damage; recognition of illegal decisions, actions or omissions of the authority or local self-government, their officials and officials and other means established by law or contract. As we can see, the current legislation is about ensuring a legal result in the case of the application of certain mechanisms for the protection of civil law. It is logical in such circumstances to assume that the restoration of the statute of limitations is also intended to ensure such a result.

Both of these concepts deal with the consequences of the introduction of legal tools, without analyzing the legal nature of the phenomenon. This is not surprising, because for a long time it was its external manifestation that was the subject of research, and based on the result, attempts were made to explain the real essence. The fact that until relatively recently the courts often pointed to the possibility of renewing the deadline for filing a statement of claim, if the reason for missing the deadline for filing a lawsuit was considered valid. And in the Code of Administrative Procedure a similar mechanism is used today. This vague approach, when the statute of limitations is given not material, but purely procedural features, does not allow to understand the true characteristics of the object of study. 
Complicating matters is that different concepts have almost the same consequences as if the lawsuit had been filed in time.

So is the exercise of the commented judicial power a factual statement that according to these requirements the statute of limitations has not been extinguished or extended? Of course not. Restoration of the statute of limitations can not be further qualified as an extension, as it happens in the literature [5, p. 45-46], it does not affect the change in the duration of the ancient course. Analysis of Part 5 of Article 267 of the Civil Code makes it possible to conclude that the restoration of the statute of limitations by the court in cases of seriousness of the reason for its omission is possible only to protect the right. The judicial body may not renew a certain statute of limitations, which is expressed in years, months, etc. After all, in the case of extension of any term is extended and the duration of a particular substantive right due to the holder. In our case - a claim. In other words, the creditor could exercise his security authority for an additional period of time by suing. When the statute of limitations is renewed, there is no new opportunity to file a lawsuit. The court only grants a protective requirement to enforcement.

From this point of view, it would be unjustified to equate judicial protection of a subjective right in the event that the plaintiff misses the statute of limitations in the absence of the defendant's statement with the restoration of the statute of limitations. In fact, the situations described in Part 3 and Part 5 of Art. 267 of the Civil Code of Ukraine, have a fundamental difference precisely because of their different nature. The first concerns the possibility of exercising the substantive right to sue outside its existence. This does not seem to be true, because the ability to exercise the same right at the same time in different situations is made conditional on the existence of a party's application for the expiration of the statute of limitations, and in addition is deprived of a real legal basis. Instead, the restoration of the statute of limitations is not about the realization of the claim after the term of its existence, but about the exercise of another protective subjective right - to obtain judicial protection (enforcement of the protective right under duress).

Thus, the court's decision to restore the statute of limitations on a particular claim is in no way identical to the protection of the infringed right and the satisfaction of the creditor's claims. With the renewal of the statute of limitations, the plaintiff has the opportunity to implement the claim. But this is only one component of the concept of protection of violated civil rights. For its actual implementation, in addition to restoring the statute of limitations, it is also necessary to find out all the facts that indicate the mechanism of the relationship between the parties, the nature of the violation, analyze the plaintiff's claims and so on. 


\title{
References:
} $208 \mathrm{p}$.

1. Kolodiy AM Principles of Ukrainian law. K .: Юрінком Інтер, 1998,

2. Guyvan P.D. Statute of limitations. Monograph. Kharkiv : Pravo, 2012. 448 p.

3. Dobrovolsky AA Claim form of protection of rights. М. : Изд-во Моск. ун-та, 1965. 189 p.

4. Kirillova M.Ya. Statute of limitations. М. : Юридическая литература, $1966.156 \mathrm{p}$.

5. Frolov Yu., Frolova G. Some problems of application of limitation periods, their differences from other terms in civil law. Підприємництво, господарство і право. 2001. № 10. Рp. 45-47.

DOI https://doi.org/10.30525/978-9934-588-92-1-35

\section{УСНІ ПОЯСНЕННЯ УЧАСНИКІВ СПРАВИ ЯК ФОРМА ДОКАЗІВ В ЦИВІЛЬНОМУ СУДОЧИНСТВІ УКРАЇНИ}

\author{
Короєд С. О. \\ доктор юридичних наук, дочент, \\ професор кафедри права \\ Приватного вищого навчального закладу Університету Короля Данила \\ м. Івано-Франківськ, Украӥна
}

Цивільне судочинство $є$ найпоширенішою і пріоритетною формою судового захисту порушених прав, адже саме в системі загальних судів в порядку цивільного судочинства розглядаються і вирішуються справи за участю громадян, які $\epsilon$ безпосередніми учасниками цивільних, сімейних, трудових, земельних та інших правовідносин, а відтак лише їм добре відомі обставини існування підстав виникнення, зміни та припинення таких правовідносин, а також причини спорів, які при цьому виникають у зв'язку із діями самих сторін. Як справедливо зауважив М.К. Треушніков, сторони можуть помилятися, давати фактам свою інтерпретацію, по-своєму пояснювати факти. Але за будьяких умов сторони є носіями певної доказової інформації про факти, а їх пояснення $є$ доказами [1, с. 157]. Пояснення сторін можуть дати суду важливий матеріал для визначення предмету доказування, кола доказових фактів тощо [2, с. 207]. Це забезпечується завдяки усності 